\title{
A simple, non-radioactive DNA fingerprinting method for identifying patrilines in honeybee colonies
}

\author{
Martin Beye ${ }^{a *}$, Peter Neumann ${ }^{a}$, Jana Schmitzováb, \\ Jaroslav Klaudiny ${ }^{\mathrm{b}}$, S̆tefan Albert ${ }^{\mathrm{b}}$, Jozef $\breve{S}$ imúth $^{\mathrm{c}}$, \\ Marius Felder ${ }^{c}$, Robin F.A. Moritz ${ }^{\mathrm{a}}$
}

aInstitut für Molekulare Ökologie, Martin-Luther-Universität Halle,

Kröllwitzer Str. 44, 06099 Halle, Germany

${ }^{b}$ Laboratory of Genetic Engineering, Institute of Chemistry, Slovak Academy of Sciences,

Dúbravska cesta 9, SK-842 38 Bratislava, Slovakia

'LB Genetik, Universitaet Kaiserslautern, Postfach 3049, D-67653 Kaiserslautern, Germany

(Received 6 October 1997; accepted 21 December 1997)

\begin{abstract}
Primers were derived flanking a microsatellite motif of the cloned Z-locus. The PCR product of the Z-locus was variable in size and up to four alleles were found in a sample of 11 workers within one colony. Using the combination of three loci, the $Z$, the $Q$ (both linked to the sex locus) and a royal jelly protein gene (RJP57-1) we were able to discriminate five patrilines in the 11 worker sample. Using the well established microsatellite technology, however, seven and six patrilines could be identified. The technique may enable laboratories which lack an isotope facility and equipped with only a PCR thermocycler and agarose gel apparatus to study the polyandrous mating system of the honeybee in a variety of different contexts. (1) Inra/DIB/AGIB/Elsevier, Paris
\end{abstract}

fingerprinting / patriline / mating / honeybee / Apis mellifera / PCR

\section{INTRODUCTION}

The number of matings of honeybee queens can vary dramatically from six up to 28 in natural populations $[10,16,18]$.
The multiple mating system results in a genetic subfamily structure of a honeybee colony: super-sisters are sired by the same haploid drone father, while half-sisters have different drone fathers. This causes a

\footnotetext{
* Correspondence and reprints

E-mail: beye0736@mailszrz.zrz.tu-berlin.de
} 
large intracolonial genetic variance, which is of substantial interest for both evolutionary and behavioral genetics $[6,17,20]$.

In recent years a wide range of different DNA techniques have been established for honeybees to identify the subfamily structure of colonies such as multilocus DNA fingerprinting $[5,15]$ and RAPD (random amplified polymorphic) marker technology $[11,12]$. More recently microsatellite technology has been developed for honeybees and proved to be a powerful tool for exactly determining the number of patrilines and the intracolonial relatedness [10]. However, this technique is time consuming and requires sophisticated equipment such as a radioactive isotope laboratory and large polyacrylamide gels.

Here we present a very simple and fast method for identifying patrilines of the honeybee, which does not require radionucleotide labelling. We used sequence specific primers of the Q-locus [13], the Z- locus $[3,4]$ and the locus of royal jelly protein RJP57-1 [1, 14], which produce distinct and highly variable DNA products in the PCR reaction. The obtained DNA fragments have sufficient size differences to easily be distinguished in agarose or small polyacrylamide gel electrophoresis.

\section{MATERIALS AND METHODS}

\subsection{Bee samples}

Adult honeybee workers were taken from the outer frames of two colonies A and B (11 workers and 7 drones each) at the apiary of the Bayrische L.A. für Bienenzucht (Germany) in June 1995.

\subsection{DNA isolation}

DNA was phenol extracted from single workers following routine protocols [2] with some minor changes:

1) workers were incubated in insect ringer solution ( $127 \mathrm{mM} \mathrm{NaCl}, 1.5 \mathrm{mM} \mathrm{CaCl}_{2}, 5 \mathrm{mM}$
$\mathrm{KCl}, \mathrm{pH} 7.4$ with $\mathrm{NaOH}$ ) for at room temperature before extraction;

2) worker thoraces were homogenized in $400 \mu \mathrm{L}$ of DNA extraction buffer $(100 \mathrm{mM}$ $\mathrm{NaCl}, 100 \mathrm{mM}$ Tris- $\mathrm{HCl}(\mathrm{pH} 8.0), 10 \mathrm{mM}$ $\mathrm{NaCl}, 0.1 \%$ SDS);

3) DNA was resuspended in $30 \mu \mathrm{LddH} \mathrm{H}_{2} \mathrm{O}$.

\subsection{Microsatellite fingerprinting}

We used a set of DNA-microsatellites which was developed by Estoup et al. [9]. Multiplex PCR was performed using two pairs of loci (A43-B124, A76-A107) and the standard protocols of Estoup et al. [9, 10].

\subsection{Non-radioactive fingerprinting: the $Z, Q$ and RJP 57-1 locus}

The $1.7 \mathrm{~kb}$ cloned $\mathrm{Z}$-locus fragment $[3,4]$ was sequenced using an automated sequencer following the manufactor's instructions. Primers (figure la) were designed which flanked an approximately $130 \mathrm{bp}$ long microsatellite (TTTC) ${ }_{n}$ motif in this fragment. The overall length of the resulting PCR product was about $650 \mathrm{bp}$, which can be resolved in an agarose gel. The primers for PCR amplification of the RJP 57-1 locus were designed from the cDNA sequence of RJP 57-1 [1]. The primers were derived from region $\mathrm{R} 1$ (nucleotides 1261 to 1284) and R2 (nucleotides 1640 to 1666 ) (figure $l b$ ). The primers (figure $l c$ ) and the PCR conditions for the Q-locus have been previously described [13]. PCR amplifications of $\mathrm{Z}, \mathrm{Q}$ and RJP 57-1 were carried out as described in table I.

\subsection{Electrophoresis and determination of genotypes}

Non-radioactive amplification products were separated on $3 \%$ agarose gels (Ultra Pure DNA grade, BioRad Laboratories) at $7 \mathrm{~V} / \mathrm{cm}$ or on small $8 \%$ polyacrylamide gels for $2 \mathrm{~h}$ at $200 \mathrm{~V}$ with a $100 \mathrm{bp}$ ladder as size standard. Each electrophoresis was performed following the routine protocols of Sambrook et al. [21].

Radioactive amplification products were electrophorized on $6 \%$ polyacrylamide sequen- 
a. $\mathrm{Z}$ locus primers
Z1
5'-AGCCGACTAATATAATTTC-3'
$\mathrm{Z2}$
5'-GGAAAGAGGGTTATTATAC-3'

b. RJP 57-1 locus primers

$\begin{array}{ll}\text { R1 } & \text { 5'-TGTAGATGACTTAATGAGAAACAC-3' } \\ \text { R2 5'-ATGTAATTTTGAAGAATGATGAACTTG-3' }\end{array}$

c. Q- locus primers

Q1 5'-AGTGCAGCCAGCTACTGAGAG-3'

Q2 5'AGTGCAGCCACGTGCCTGAAT-3'

Figure 1. Primers used in the non-radioactive fingerprinting designed from sequences of the $Z$, RPJ57-1 and Q-locus.

Table I. PCR conditions of the Z, Q and RJP57-1 primers.

\begin{tabular}{|c|c|c|c|}
\hline $\begin{array}{l}\mathrm{MgCl}_{2} \\
\text { primer }\end{array}$ & $\begin{array}{l}\text { Z primers } \\
1.5 \mathrm{mM} \\
400 \mathrm{nM}\end{array}$ & $\begin{array}{c}\text { Q primers } \\
1.5 \mathrm{mM} \\
400 \mathrm{nM}\end{array}$ & $\begin{array}{c}\text { RJP57-1 primers } \\
2.5 \mathrm{mM} \\
500 \mathrm{nM}\end{array}$ \\
\hline number of cycles & 47 & 47 & 30 \\
\hline step 1 & $3 \min 94^{\circ} \mathrm{C}$ & $3 \min 94^{\circ} \mathrm{C}$ & $3 \min 94^{\circ} \mathrm{C}$ \\
\hline step 2 & 30 s $94^{\circ} \mathrm{C}$ & $1 \min 94^{\circ} \mathrm{C}$ & 30 s $94^{\circ} \mathrm{C}$ \\
\hline step 3 & 45 s $49^{\circ} \mathrm{C}$ & $1 \min 55^{\circ} \mathrm{C}$ & 30 s $54^{\circ} \mathrm{C}$ \\
\hline step 4 & $1 \min 72^{\circ} \mathrm{C}$ & $2 \min 72^{\circ} \mathrm{C}$ & $1 \min 72^{\circ} \mathrm{C}$ \\
\hline step 5 & $10 \min 72^{\circ} \mathrm{C}$ & $10 \min 72^{\circ} \mathrm{C}$ & $10 \min 72^{\circ} \mathrm{C}$ \\
\hline
\end{tabular}

cing gels for $5.5 \mathrm{~h}(\mathrm{~A} 76 / \mathrm{A} 107)$ or $5 \mathrm{~h}$ (A43/B 124) together with M13mp18 control DNA sequencing reactions as size standard on the same gel. Alleles were scored as fragment lengths in base pairs.

\section{RESULTS AND DISCUSSION}

The PCR fragment of the Z-locus [4] proved to be polymorphic even in the progeny of a single queen (figure $2 a$ ). Four alleles were detected in a sample of 11 workers of colony $\mathrm{B}$, three DNA length polymorphism ranging from 610 up to 670 bp and a 'null allele'. These 'null alleles' occur if PCR products are lacking at the tested locus [7, 19].

The protein of the cDNA clone RJP57-1 $[1,14]$ possesses on its C-terminus, a 100 amino acid residue long repetitive region consisting of a 20 -fold repeated sequence motif XQNXX. Amplification of this region revealed length polymorphism (Albert et al., unpublished data). Four and 
$\mathbf{A}$

colony B

workers

$\begin{array}{llllllllllllll}15 & 21 & 18 & 3 & 19 & 12 & \text { M } & 32 & 20 & 7 & 26 & 34 & \text { M } \overline{130}\end{array}$

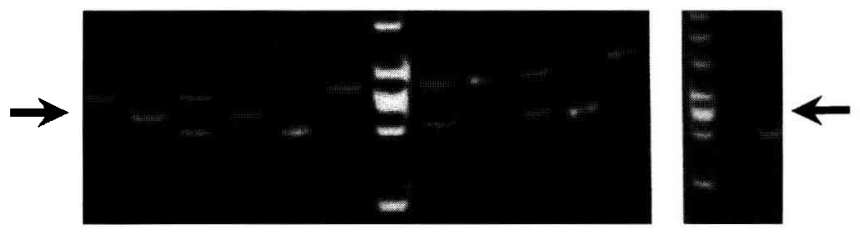

B

colony A

workers drones

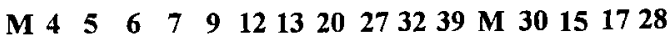

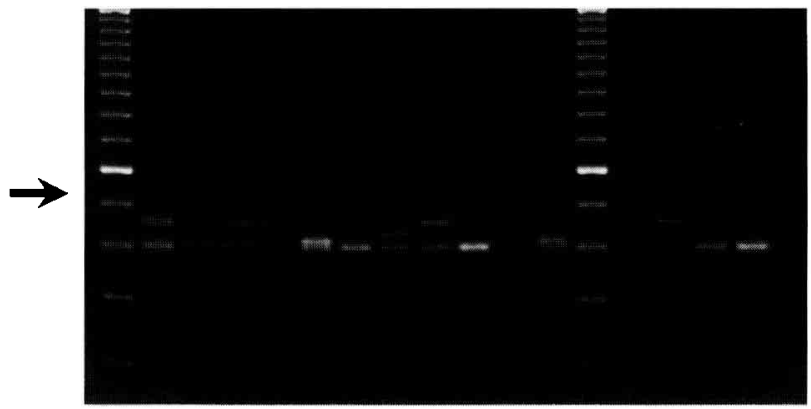

Figure 2.a. Polyacrylamide gel showing the Z-locus PCR product of 11 workers and two drones of colony B. The Z-locus PCR product showed a high variability within one colony: three length polymorphism and one 'null allele' (see text). The fragment size of the alleles were: 670, 640,610 $\mathrm{bp}$ and 'null allele'. The allele length was determined in comparison to a $100 \mathrm{bp}$ DNA ladder M as a size standard (GIBCO BRL, a 650 bp band (above 700 bp band) is indicated by an arrow). b. Agarose gel showing the RJP57-1 locus PCR product of 11 workers and four drones of colony A. The RJP57-1 locus PCR product is highly variable within one colony and four different alleles $(460,435,420,405 \mathrm{bp})$ could be identified. The allele length was determined in comparison to a 100 bp DNA ladder $M$ as a size standard (GIBCO BRL, the 600 bp band is indicated by an arrow).

two alleles were found in the 11 worker progenies of colony $\mathrm{A}$ (figure $2 \mathrm{~b}$ ) and colony $B$, respectively, ranging from 405 up to 460 bp in size.

Using the combination of the two variable loci described here and the Q-locus $[8,13]$ we are able to discriminate several patrilines of the honeybee colony. Although $\mathrm{Q}$ and $\mathrm{Z}$ are two linked markers (both linked to the sex locus), this does not necessarily influence the detection of patrilines. The characteristic combination of alleles at all three three loci (Q, Z, RJP57-1; table II) was used to determine the number of patrilines. We compared the power of this tech- 
nique to the number of patrilines determined by four informative loci microsatellite fingerprinting [10] using four informative loci (A76, A 107, B 124 and A43; tables $I I$ and $I I I)$.
Five patrilines were detected in colony A using the non-radioactive fingerprint technique, but seven patrilines were identified using the microsatellite technique (table Ila). Using the information of both

Table II. Informative genotypes of the three loci Z Q RJP57-1 of colony A and B. The genotype of the queen was determined by the haploid drone offspring. Only informative bands ("father alleles') different to those of the queen are listed in the worker progeny. Some 'father alleles' cannot be unambiguously determined as they either be identical to one or two of the queen's alleles or represent a 'null allele'. The resulting patrilines (a-e) were compared to the microsatellite technology $(=\mathrm{ms}$ technology) $(1-7)$. Combining both data sets an overall number of nine patrilines was identified (I-IX). (nd = missing value).

Sample Genotype (bp) Genotype (bp) Genotype (bp) Patrilines Patrilines by Overall number RJP57-1 locus Q-locus Z-locus ms technology of patrilines

\section{a. Colony $\mathbf{A}$}

\begin{tabular}{|c|c|c|c|c|c|c|}
\hline $\begin{array}{c}\text { Queen genotyp } \\
\text { Worker }\end{array}$ & $405 / 460$ & $700 / 0$ & $560 / 0$ & & & \\
\hline 6 & & & 700 & $\mathrm{a}$ & 1 & I \\
\hline 7 & & & 700 & $\mathrm{a}$ & 1 & I \\
\hline 27 & & & 700 & $\mathrm{a}$ & 2 & II \\
\hline 12 & & nd & nd & a & 2 & II \\
\hline 13 & 435 & 600 & & b & 3 & III \\
\hline 9 & 420 & 600 & & $\mathrm{c}$ & 3 & IV \\
\hline 4 & & & & d & 4 & V \\
\hline 5 & & 600 & & $\mathrm{e}$ & 4 & VI \\
\hline 20 & & & 700 & a & 5 & VII \\
\hline 32 & 435 & 600 & & b & 6 & VIII \\
\hline 39 & 420 & 600 & & c & 7 & IX \\
\hline
\end{tabular}

\section{b. Colony B}

\begin{tabular}{lccccc}
\hline $\begin{array}{l}\text { Queen genotype 405/460 } \\
\text { Worker }\end{array}$ & $700 / 700$ & $610 / 0$ & & & \\
3 & 680 & 640 & $\mathrm{a}$ & 1 & I \\
2 I & 680 & 640 & $\mathrm{a}$ & $\mathrm{I}$ & I \\
15 & nd & 670 & $\mathrm{~b}$ & 2 & II \\
18 & & 670 & $\mathrm{~b}$ & 2 & II \\
26 & & & $\mathrm{c}$ & 3 & III \\
32 & 600 & 670 & $\mathrm{~b}$ & 3 & IV \\
12 & 600 & & $\mathrm{~d}$ & 4 & V \\
19 & & 670 & $\mathrm{e}$ & 4 & VI \\
34 & & 670 & $\mathrm{~b}$ & 5 & VII \\
7 & & 670 & $\mathrm{~b}$ & 5 & VII \\
20 & & & 5 patrilines & 6 patrilines & 8 patrilines \\
& & & & & \\
\hline
\end{tabular}


Martin Beye et al.

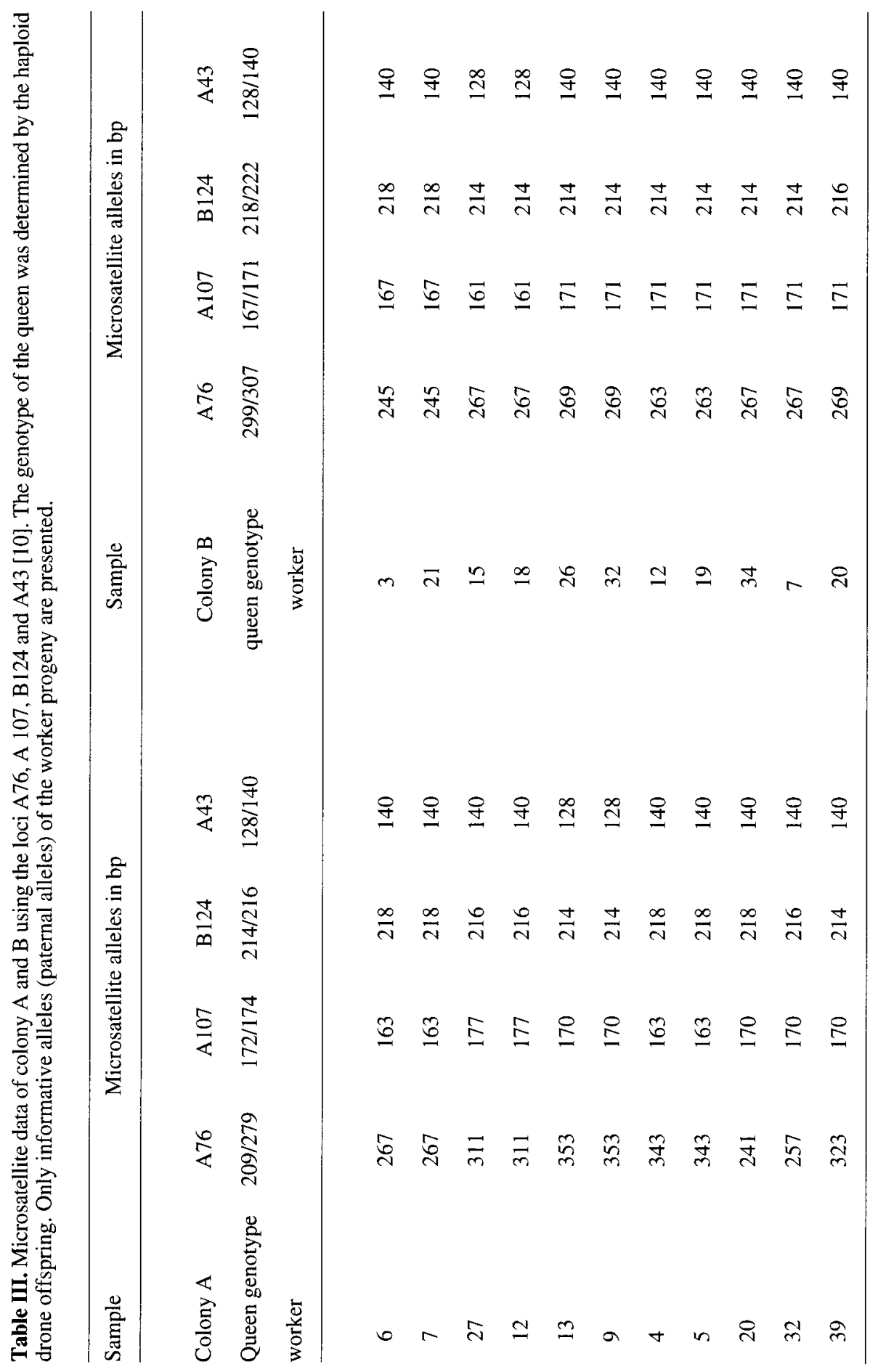


techniques, nine patrilines were identified. In colony B the resolution was similar: five patrilines were detected using the single locus data of Q, Z and RJP57-1, whereas six patrilines were found in the microsatellite fingerprinting (table IIb). The resulting overall number of patrilines using the information of all loci was eight.

The number of patrilines determined by the non-radioactive fingerprinting was less than the number of patrilines found in microsatellite fingerprinting. The average number of alleles per locus was 3.3 (colony A) and 3 (colony B) in the nonradioactive fingerprinting while the average allele number in the microsatellite fingerprinting was slightly higher: 4.7 alleles per locus in colony $A$ and 3.7 in colony $\mathrm{B}$. The higher number of patrilines found in the microsatellite fingerprinting could be explained by the higher number of alleles detected per locus and by using a 4th locus in the microsatellite fingerprinting approach. A higher resolution of patrilines was obtained using the combined data of both techniques.

In many cases, the resolution of the non-radioactive technique might be sufficient to resolve questions related to the mating frequency. The procedure for determining patrilines is a relatively simple, fast and cheap method compared to the more labour-intensive and complex technique of microsatellite technology using radioactive or fluorescent labelled DNA fragments and large sequencing gels. In our laboratory we found that the analysis of the PCR fragments with just agarose gels was about twice as fast as large PAGEs (which did not include the exposure time of films) and reduces the costs to two thirds. This technique may also enable laboratories with just an agarose gel apparatus and a PCR thermocycler to study the polyandrous mating system of the honeybee in a variety of different contexts. This non-radioactive technique may become even more powerful, if primers of addi- tional highly variable loci (e.g. STS primers (sequence-tagged site) derived from RAPD markers) become available.

\section{ACKNOWLEDGMENT}

This study was financially supported by the DFG and the Scientific Grant Agency of Ministry of Education of Slovak Republic and the Slovak Academy of Sciences (2/1098/95) and the BMWB. We thank Rosemarie Hoffmann for technical assistance and Dieter Mautz for providing bee samples.

Résumé - Une méthode d'analyse simple et non radioactive d'empreinte génétique pour identifier les lignées paternelles des colonies d'abeilles. $\mathrm{La}$ technique des microsatellites a été développée chez l'abeille (Apis mellifera L.) pour déterminer le nombre exact de lignées paternelles et le degré de parenté entre membres de la même colonie. Nous avons mis au point une technique qui, contrairement à celle des microsatellites, ne nécessite pas l'utilisation de radioisotopes et avons comparé les deux méthodes quant à leur précision. Des amorces (figure 1a) ont été développées à partir de régions situées de part et d'autre d'un motif microsatellite du locus $Z$ et on a trouvé par PCR jusqu'à quatre allèles différents dans un échantillon de 11 ouvrières provenant de la colonie B (figure 2a). À l'aide d'un fragment RJP57-1, qui renferme un motif codant pour une protéine de gelée royale, la PCR a permis de mettre en évidence jusqu'à quatre allèles différents dans un échantillon de 11 ouvrières de la colonie A (figure $2 b$ ). En combinant les trois locus Z, Q et RJP57-1 (tableau I), cinq lignées paternelles ont été mises en évidence dans la colonie A et cinq dans la colonie B (tableau II, échantillons de 11 individus par colonie). Par la technique des microsatellites (tableau $I I I$ ), on a trouvé un nombre de pères légèrement plus 
élevé: 7 et 6 respectivement (tableau II). Cette technique pourrait permettre aux laboratoires de petite taille, équipés seulement d'un thermocycleur PCR et d'une cuve d'électrophorèse pour gel d'agarose, d'étudier le système de reproduction polyandre de l'abeille. (C) Inra/DIB/AGIB/Elsevier, Paris

\section{Apis mellifera / empreinte génétique / lignée paternelle / PCR / accouplement}

\section{Zusammenfassung - Eine einfache, nicht-radioaktive DNA Fingerprint- methode zur Bestimmung der Patrili- nienanzahl in Bienenvölkern. Es wur-} den Primer $(A b b . l a)$ aus flankierenden Bereichen eines Microsatellitenmotivs des Z-Locus entwickelt und etabliert. Bis zu 4 Allele des Z-Fragments wurden in einer Stichprobe von 11 Arbeiterinnen einer Kolonie in der PCR (Polymerasen-Ketten-Reaktion) gefunden ( $A b b .2 a)$. Mit Hilfe des RJP57-1 Fragments, das ein Motiv eines Gelée-Royal Proteins enthält, konnten bis zu 4 Allele in der Stichprobe nachgewiesen werden $(A b b .2 b)$. Durch die Kombination der 3 Loci, Z, Q und RJP57-1) (Tabelle I) konnten 5 Patrilinien in einer Stichprobe von 11 Individuen nachgewiesen werden (Tabelle $I$ ). Die Anzahl, der durch die MikrosatellitenTechnologie (Tabelle III) nachgewiesenen Väter, war mit 6 und 7 (Tabelle II) in der gewählten Stichprobe nur unwesentlich höher. Diese Technik könnte selbst kleineren Laboratorien ermöglichen, die nur mit einem PCR-Thermocycler und einer Agarose-Gel-Kammer ausgestattet sind, das polyandrische Paarungssystem der Honigbiene zu studieren. $\odot$ Inra/DIB/AGIB/Elsevier, Paris

\section{Honigbiene / Begattung / Patrilinie / Fingerprint / PCR}

\section{REFERENCES}

[1] Albert $\breve{S}$., Klaudiny L., Simúth J., Newly discovered features of the updated sequence of royal jelly protein RJP57-1, longer repetitive region on C-terminus and homolgy to Drosophila melanogaster yellow protein, J. Apic. Res. 35 (1996) 63-68.

[2] Beye M., Raeder U., Rapid DNA preparation from bees and \% GC fractionation, Bio. Techniques 14 (1993) 372-374.

[3] Beye M., Epplen C., Moritz R.F.A., Sex linkage in the honey bee Apis mellifera L. detected by multilocus DNA fingerprinting, Naturwissenschaften 81 (1994) 460-462.

[4] Beye M., Crozier R.H., Crozier Y.C., Moritz R.F.A., Mapping the sex locus of the honeybee (Apis mellifera), Naturwissenschaften 83 (1996) $424-426$.

[5] Blanchetot A., Genetic relatedness in honeybees as established by DNA fingerprinting, J. Hered. 82 (1991) 391-396.

[6] Breed M.D., Bennet B., Kin recognition in highly eusocial insects, in: Fletcher D.J.C., Michener C.D. (Eds.), Kin Recognition in Animals, Wiley, Chichester, 1987, pp. 243-285.

[7] Callen D.E., Thampson A.D., Shen Y., Philips H.A., Richards R.I., Mulley J.C., Sutherland G.R., Incidence and origin of 'null' alleles in the (AC)n microsatellite markers, Am. J. Hum. Genet. 52 (1993) 922-927.

[8] Dreller C., Fondrk M.K., Page R.E., Genetic variability affects the behavior in a feral honeybee colony, Naturwissenschaften 82 (1995) 243-245.

[9] Estoup A., Solignac M., Harry M., Cornuet J.M., Characterisation of (GT)n and (CT)n microsatellites in two insect species: Apis mellifera and Bombus terrestris, Nucleic Acids Res. 21 (1993) 1427-1431

[10] Estoup A., Solignac M., Cornuet J.-M., Precise assessment of the number of partilines and genetic relatedness in honeybee colonies, Proc. R. Soc. Lond. B 258 (1994) 1-7.

[1 1] Fondrk M.K., Page R.E., Hunt G.J., Paternity analysis of worker honeybees using random amplified polymorphic DNA, Naturwissenschaften 80 (1993) 226-231

[12] Hunt G.J., Page R.E., Patterns of inheritance with RAPD molecular markers reveal novel types of polymorphism in the honey bee, Theor. Appl. Genet. 85 (1993) 15-20.

[13] Hunt G.J., Page R.E., Linkage analysis of sex determination in the honey bee (Apis mellifera L.), Mol. Gen. Genet. 244 (1994) 512-518. 
[14] Klaudiny J., Hanes J., Kulifajová J., Albert S̆., Šimúth J., Molecular cloning of two cDNAs from head of the nurse honeybee (Apis mellifera L.) coding for related proteins of royal jelly, J. Apic. Res. 33 (1994) 105-111.

[15] Moritz R.F.A., Meusel M.S., Haberl M., Oligonucleotide DNA fingerprinting discriminates super and half-sisters in honeybee colonies (Apis mellifera L.), Naturwissenschaften 78 (1991) 422-424.

[16] Moritz R.F.A., Kryger P., Koeniger G., Koeniger N., Estoup A., Tingek S., High degree of polyandry in Apis dorsata queens detected by microsatellite variability, Behav. Ecol. Sociobiol. 37 (1995) 357-363

[17] Moritz R.F.A., Kryger P., Allsopp M.H., Competition for royalty in bees, Nature 384 (1996) 31
[18] Neumann P., The genotypic composition of honeybee colonies, Ph. D. thesis., MartinLuther-Universität Halle, Halle, 1998.

[19] Oldroyd B.P., Smolenski A.J., Cornuet J.-M., Wongsiri S., Estoup A., Rinderer T.E., Crozier R.H., Levels of polyandry and intracolonial genetic relationships in Apis dorsata (Hymenoptera: Apidae), Ann. Entomol. Soc. Amer. 89 (1996) 276-283

[20] Robinson G.E., Page R.E., Genetic determination of guarding and undertaking in honeybee colonies, Nature 333 (1988) 356-358.

121 Sambrook J., Fritsch E.F., Maniatis T., Molecular Cloning - A Laboratory Handbook, 2nd ed., Cold. Spring Harbour Laboratory Press, New York, 1989. 